\title{
Toward a Cultural Ecology of Architectural Glass in Early Modern Northern Europe
}

Morgan $\mathrm{Ng}$

You shall have sometimes fair houses so full of glass, that one cannot tell where to become, to be out of the sun or cold. ${ }^{1}$ Francis Bacon (1625)

For champions of architectural modernism in the early decades of the twentieth century, the extensive use of glazed fenestration was a hallmark of what they audaciously termed the International Style. This new architectural idiom, characterized by vitreous expanses enveloping openwork structures of steel and reinforced concrete, first emerged in Germany, France, and the Netherlands. ${ }^{2}$ Only since the Second World War, however, has the style truly come to live up to its ambitious name. Advances in the standardized production and assembly of building materials, as well as mechanical systems for regulating the temperatures of building interiors, have accelerated its proliferation across the world - despite the great diversity of regional environments or pre-existing building traditions. In the words of one contemporary critic, such modernist architecture disregards the "contingencies of climate and the temporally inflected qualities of local light," with the goal of imposing "a condition of absolute placelessness" in these disparate geographies. ${ }^{3}$ As a result of its global triumph, the near-universal spread of window glass - and the architectural transparency to which it has given rise - is now perceived as a paradigmatic expression of the modern era.

It may come as a surprise, then, that early modern observers would have regarded the material's ever-widening geography in a far more equivocal light. Adam Smith, for example, saw the rising production and consumption of plate glass in own his time and place as the logical outgrowth of local environmental conditions. In the frigid realms of early modern 
northern Europe, where glass first underwent a slow progression from rare luxury to common amenity, ${ }^{4}$ this "beautiful and happy invention" served to "[let] in the heat and the light, and [keep] out the wind and the rain" endemic to that inhospitable part of the world. ${ }^{5}$ Yet little more than a century earlier, Sir Francis Bacon, the great defender of the new sciences, took a contrasting position to Smith's geographical determinism. Bacon ridiculed the exorbitant window glazing of the elite as a practice inappropriate for any climate. The dazzlingly fenestrated "lantern houses" of Renaissance England were so porous, and their enormous windows so prone to shattering, that they left their occupants more vulnerable than ever to the elements (plate 1). His contemporary, Sir Henry Wotton, attacked the environmental absurdity in even sharper terms: such excessively "luminous roomes" in "northerne climes would be too could, in southerne, too hot." ${ }^{\prime 6}$ Where Smith drew a positive relationship between glazing and interior comfort, Bacon and Wotton identified buildings whose degree of fenestration had exceeded the critical point, inverting that functional correlation.

In this essay, I confront the apparent contradiction that the use of a particular building material could be simultaneously conceived both to follow and subvert the logic of its natural surroundings. More precisely, my study traces the implications of this paradox in the secular architecture of late-sixteenth- and seventeenth-century northern Europe - charting a geographically-specific ecology of window glass in the Low Countries, as well as their mercantile spheres of influence in the Hanseatic states, England, and what is now northwestern France. Beginning in the late Renaissance, this commercially, culturally, and geographically interconnected network of sites witnessed a confluence of related architectural trends: a significant increase of glazing in domestic and civic structures, a rising preference for colourless glass over stained glass, refinements in the durability and transparency of glass manufactures, and the material's site-specific application in innovative new building typologies. Glazing brought novel experiential qualities to early modern buildings, and 
occasioned a heightened cultural consciousness of architecture's interdependency - and antagonism - with its environmental context.

The complex interrelationships, between glazed architecture and its environment, may be best described by what I shall call synthetic vernacularism. By this I mean the architectural application of a synthetic material - which could potentially be manufactured anywhere ${ }^{7}$ - in a manner that is responsive to regional geographic and cultural conditions. On its face, the term might appear oxymoronic. In architectural parlance, vernacular typically denotes building traditions that rely on locally procured construction materials: stone from a nearby quarry, for instance, or the wood of a native species. By contrast, a synthetic material such as glass is the outcome of a sophisticated process of production, not simply extraction. Moreover, its constituent elements (silica sand and plant ash) are often gathered from farflung locations. And while such processes of manufacture often have determinate places of origin, they are not in themselves site-specific. ${ }^{8}$

At the same time, however, northern European builders carefully adapted their use of glass to the specificities of their local environments in ways that nevertheless should be considered vernacular. For habitations in chilly climates or cramped urban quarters that formerly enjoyed only limited daylight or outdoor views, northern European builders strategically designed glazed fenestration to maximize the architecture's visualenvironmental permeability, to profound effect on the experience of interior spaces and the spatial organization of daily life. Such environmentally contingent inflections of early modern architectural practice represent a reality that is all but forgotten in today's homogeneous climate-controlled and electrically illuminated buildings. The contextual nature of early modern glazing contradicts modernism's geographically deracinated aesthetic of architectural transparency, an aesthetic now treated like the outcome of an inevitable developmental trajectory. Methodologically speaking, a historically grounded account of 
architectural glass would shift our analysis from modernism's teleological temporal axis, and instead situate the material's use within the spatial matrix of geography.

To frame our study in these terms is to regard the natural environment as an irreducible, yet insufficient, denominator in architectural design and construction. Art historians have rightly challenged an earlier tradition of Kunstgeographie, which sought to attribute stylistic developments to fixed categories of national character, race, and geographic origin. ${ }^{9}$ Our study of architecture might nuance these disciplinary insights, which have so far mostly concerned the figural arts. ${ }^{10}$ More than paintings and sculpture, buildings are planted in physical space, making geography an inescapable part of their reality. Yet the environment's influence on architecture is not linear, nor straightforwardly causal. Even while fulfilling local needs, early modern architectural glass was a thoroughly overdetermined cultural product. This phenomenon has received insufficient attention in art-historical scholarship (due to longstanding historiographical biases that I shall address), for the early modern rise of colourless, non-figural glazing converged in unexpected ways with the dominant visualcultural trends of the period, from the adoption of architectural classicism to the development of novel modes of pictorial and scientific representation. In their efforts to produce brilliant spaces that frequently mimicked the architecture of foreign regions, northern builders sometimes invented site-specific uses for glass that, paradoxically, defied the logic of their local climates or even compromised interior comfort. While regionally localized, such innovations frustrate any naïve conception of vernacular architecture as solely the organic outgrowth of native resources and geographic conditions. The present essay seeks to tease out not only the reciprocity, but also the unresolved tensions, in the early modern use of this synthetic material and its dialectical relationship with the natural environment.

\section{Late-Renaissance Architectural Glass and its Historiography}


Around 1600, a fashion for building great glazed facades, originating in the commercial centres of the Low Countries, swept across the cities and towns around the North and Baltic Seas. Typifying this class of buildings were the guildhalls in Antwerp's great market square, constructed soon after the site's earlier structures were destroyed by fire in 1576. Such architecture inherited its remarkable diaphaneity from gothic achievements in fenestration, while introducing a lasting trend for nearly floor-to-ceiling glazing to new civic and domestic contexts (plate 2). ${ }^{11}$ Moving eastward, this architectural type settled in Hanseatic port cities traditionally interconnected economically and culturally with the Netherlands through trade. In Bremen, for instance, local builder Lüder von Bentheim performed a series of architectural facelifts on important civic buildings that transformed their late-gothic facades into shimmering surfaces surrounding the market square (see plate 9). ${ }^{12}$ Inland from Bremen, precious extant samples of this architecture may still be found in towns along the Weser River. Similar structures arose in Danzig (now Gdańsk, in modern-day Poland) through the influence of Flemish architects such as Anton van Obberghen and Abraham van den Blocke. From there, it spread as far east as Memel and Königsberg (now, respectively, Klaipeda and Kaliningrad in Latvia and Russia), as well as Riga, in modern-day Latvia. ${ }^{13}$ Whereas on the continent this style predominated in urban buildings, in England it also emerged in quite a different context: the country house. Robert Smythson contributed to the design of among the most stunning late-Elizabethan examples: Wollaton (1580-88), Longleat (completed 1580); and Hardwick Hall (1590-97) - which locals famously quipped was "more glass than wall" (see plate 1). ${ }^{14}$ At a time when glass still represented an unimaginable luxury to the masses, contemporaries marvelled at the sheer size of these glazed late-Renaissance windows.

The rising demand for flat glass intersected with both pre-existing and emerging patterns of production and distribution in these regions. The finest early modern manufactures in Europe came from glassworks concentrated in forested areas around the 
Bresle and Seine rivers, belonging to the regions of Upper Normandy and Picardy in northwestern France. ${ }^{15}$ Throughout the later Middle Ages and Renaissance, Normandy glass was universally prized for its transparency and whiteness over products from other major production centres, namely the "Rhenish glass" from the Rhineland and the adjacent regions of Burgundy and Lorraine, ${ }^{16}$ and the "Hessian glass" manufactured farther east. ${ }^{17}$ Glass production in all these regions was integrated into highly developed channels of distribution. Merchandise arrived by sea or river in Antwerp, Bruges, and Bremen, which functioned as clearinghouses for its traffic throughout Europe. ${ }^{18}$ Norman glassworks were also strategically sited near ports such as Rouen, whence their wares could easily arrive across the Channel at English ports: Hull, King's Lynn, and London. While England had imported most of its luxury window glass into the sixteenth century, by the late Tudor and Stuart periods it, too, developed a thriving domestic industry after the arrival of French and Flemish Protestant refugees, in conjunction with state support for their foreign technological expertise. ${ }^{19}$ These regional technological and mercantile systems provided the crucial material conditions for the radical use of architectural glass.

Early modern commentators recognized the superiority of northern European plateglass-working, from the manufacture of the material to its instalment in buildings. Even Giorgio Vasari, the great sixteenth-century champion of central Italian artists, acknowledged this regional division of expertise. The best stained glass demanded a base material of "luminous transparency" and the application of "clear colour without any confusion," he explained, and in the arts of window glazing and glass painting

the Flemish and the French have worked with better skill than the other nations... Transparency comes from knowing how to select glasses that are clear [lucidi] in themselves, and in this respect the French, Flemish, and English glasses are better 
than the Venetian: because the Flemish glasses are very clear and the Venetian very laden with colour. ${ }^{20}$

Vasari even attributed the "perfection" of Tuscany's glassmaking to Guglielmo de Marcillat, a French glassworker who settled in Arezzo. Indeed, sixteenth-century Italian patrons sought after immigrant glaziers, whose plate glass was sourced from northern Europe, to work on their most prestigious buildings. ${ }^{21}$ A certain Gualtieri of Antwerp worked on the windows of the Palazzo Vecchio and the Certosa del Galluzzo in Florence. Michelangelo's famous Laurentian Library was glazed using the finest available material crafted by Flemish hands. ${ }^{22}$ While Venice was universally admired for the glassworks that manufactured its delicate crystal tableware (petits verreries), the best flat glassworks (or grosses verreries) clustered around regions much farther north. ${ }^{23}$

A discrepancy between north and south manifested itself not just in the quality, but also in the quantity of the material that was used, especially in secular architecture. Early modern developments magnified the considerable disparities in fenestration size and glass usage that had already distinguished various regional strains of gothic architecture. ${ }^{24}$ Over the course of the Renaissance, Italian commentators marvelled at the remarkable amount of glazing found in prosperous regions north of the Alps, where it could be "admired not only in towns and cities, but also in villages." ${ }^{25}$ An Italian visitor to Paris during the late sixteenth century, for instance, was struck by the fact that in the houses of the city "windows are fitted not with cloth but with beautiful glasses, which are seen in great numbers." ${ }^{26}$ Conversely, Michel de Montaigne opined that his lodgings in central Italy, "lacking window glass and shutters," were "less comfortable than in France." 27 A seventeenth-century English traveller was likewise startled at the paucity of glazing, even in great palaces, throughout Italy. He reckoned that in Milan, Florence, and other towns on the peninsula "there is not one house of 
ten that hath glass in their windows" - with the effect that "one is either exposed to the air, or shut up in a dungeon." 28 Admittedly, it is difficult at present to gauge precisely the proportional differences in window glazing that distinguished northern and southern European domestic settings; to do so would require the systematic, comparative study of household inventories and original-state interiors, of which there may not be a critical mass. ${ }^{29}$ The anecdotal evidence nonetheless shows that these differences were sufficiently conspicuous to prompt the persistent notice of early modern travellers. The experiences of northern Europeans in their own glazed spaces had so shaped expectations for the brightness of their interior environments that many Italian dwellings seemed unbearably gloomy by contrast.

Taken together, this body of commentary points to two broader trends whose significance for early modern visual culture has been under-appreciated in art historical scholarship. First, beginning in the Renaissance, northern Europe witnessed the onset of a gradual transition, in which a material formerly reserved for the most exclusive ecclesiastical and princely structures appeared increasingly in more commonplace domestic architecture. ${ }^{30}$ Glass not only featured in the dramatically glazed showcase buildings mentioned above; it also brought light into the quotidian spaces of the relatively well-heeled middleclass home, largely taking the place of the dim oiled cloths previously installed in windows. As a result of their increasing commonness, glass windows underwent a legal redefinition in northern Europe around 1600, from movable goods that travelled with their owners, to immovable property fixed to the buildings. ${ }^{31}$ Second, the premium placed on interior illumination engendered a growing preference for transparent, white glass over stained glass. Over the course of the sixteenth century, the surface area of coloured window glass diminished. Pictorial elements were relegated to heraldic roundels or peripheral figures that minimally obstructed the passage of light, and they shed the rich colouration of earlier stained glass in 
favour of grisaille or yellow-tinted silver staining. The decorative effect of many such windows derived more from leading patterns than from painting. Because of shifting market demands, by the end of the century regulations on glass staining disappeared entirely from Flemish guild ordinances. ${ }^{32}$ The fashion for monumental transparent fenestration in elite civic buildings and country houses was only the most radical symptom of a general cultural quest for greater interior luminosity.

Despite its profound consequences for early modern visual culture, the rise of nondecorative architectural glass has received inadequate art-historical attention. Art historical narratives on medieval and Renaissance architectural glass typically end with the decline of figural windows around the late sixteenth century. ${ }^{33}$ Because non-pictorial windows resist the disciplinary apparatuses of formal and iconographic analysis, as well as traditional concerns with artistic authorship, they implicitly do not count in such accounts as art per se. ${ }^{34}$ Indeed, the triumph of colourless, non-figurative glass in the late Renaissance (both to outfit new windows, and to supplant existing stained glass) has even been characterized as a sort of antiRenaissance in the history of art. In a still-fundamental study from 1956, one scholar noted that "the technique of glazing descended into a gradual decline during the Renaissance, which demanded brilliance of interior illumination" above all other aesthetic considerations. For this scholar, the trend signified capitulation to a "mortifying, thoroughly anonymous mediocrity," marking the emergence of a "stage of brute barbarism." 35 Paradoxically, the use of this architectural material - during a period in which human culture ostensibly re-emerged from the so-called Dark Ages - could also elicit comparison with the destruction wrought by the Goths and Vandals.

The roots of this interpretive construct, it turns out, are at least as old as (Renaissance) art history itself. Against shifting trends in fenestration underway during his day, Vasari established an art-historical paradigm that privileged the reading of the glass window as a 
pictorial surface. According to its locus classicus, from his Vite, the art of stained glass evolved through a series of developments that conformed to the larger Vasarian narrative of teleological cultural progress, whereby all the arts attained perfection through the unfolding of three historical stages. ${ }^{36}$ Architectural fenestration, according to Vasari, first underwent a material transformation: windowpanes changed from stone to glass. Vasari mistakenly claimed that the ancients had no of use window glass, fitting their apertures instead with sheer, translucent slices of agate, alabaster or delicate (teneri) marble. ${ }^{37}$ Once they had invented window glass, however, later builders installed in their apertures either bulls-eye(occhi) or rectangular panes (piastre). The art continued to progress, he maintained, when glass became a medium of representation: "artisans then imagined creating a mosaic from the shapes (figure) of these glass pieces, which were variously coloured and assembled for the purpose of making pictures." ${ }^{38}$ In Vasari's own time, the art putatively reached its aesthetic culmination as glaziers such as Guillaume de Marcillat adopted the representational breakthroughs of Cinquecento oil painting, introducing high Renaissance principles of perspective and modelling, figural composition, and subtle coloration to their own art. ${ }^{39}$ In short, Vasari theorized that the window evolved along a linear path, from a translucent, undifferentiated surface in antiquity to a transparent, naturalistic image in the Renaissance.

However compelling, this teleological narrative fails to account for the actual artistic developments taking place in the late sixteenth century. Even in Vasari's Florence, the arrival of Flemish glaziers attended a fashion for fenestration with minimal figures overwhelmed by white glass, and eventually the disappearance of such figures altogether (plate 3). Because these works seem to undercut the pictorial status of the window, art historians have largely neglected to give them sufficient consideration.

An exception to the general scholarly oversight is Wolfgang Schöne's classic 1954 study on the representation of light in painting, which has made ambitious art-historical 
claims regarding early modern changes in glazing. Schöne has tantalizing suggested that the increasing use of colourless glass exemplified a broader cultural revolution in the pictorial conception of light: a shift from what he calls Eigenlicht to what he calls Beleuchtungslicht. Gothic stained glass consisted of lush coloured surfaces, which were designed to glow with an apparently divine brilliance that seemed to irradiate from the window itself (Eigenlicht). The gradual incursion of clear, colourless glass into Renaissance stained glass, however, transformed the window into an increasingly mundane, transparent medium for the simple transmission of light from an external, physical source (Beleuchtungslicht). By allowing "sunlight to be sensed [from] behind the window," colourless glass destroyed the illusion of the window as a miraculous light-emitting image. ${ }^{40}$ This transformation in architectural glazing, according to Schöne, paralleled a similar shift in painting: as the medieval use of gold ground for creating the appearance of the pictorial surface as its own light source (Eigenlicht) gave way to the naturalistic, three-dimensional depiction of illumination within the illusionistic world of the image (Beleuchtungslicht). ${ }^{41}$

My essay picks up, in many respects, where Schöne has left off, interrogating more fully architecture's relationship to the "sunlight...behind the window". If our analysis is to consider the built environment, we must move beyond the surface of the windowpane, which has monopolized the art-historical study of stained glass since Vasari. At this expanded scale, the secularization of vision that Schöne (and, more recently, Hans Belting ${ }^{42}$ ) suggest took place in the early modern pictorial arts also acquired spatial dimensions, as the growing demand for interior illumination extended the use of glass to domestic and civic environments well beyond the confines of ecclesiastical architecture.

\section{Architectural Classicism and Environmental Simulation}


Though art historians have bemoaned its aesthetic consequences, the spread of clear glazing was entwined with one of the signal artistic trends in Renaissance architecture: the geographical diffusion of Italianate classicism. Classical architecture, at least as it originated in ancient Rome and Greece, is an architecture conceived for Mediterranean climates. Its essential typological elements include porticos, loggias, colonnades, and terraces: semioutdoor structures that remain habitable for much of the year in balmy southern European environments. (Even the Latinate etymologies of these terms betray their Mediterranean origins. For this reason, early modern northern Europeans typically associated such words as 'portico' - an Italian vulgarization of porticus - with various colonnaded structures either from Greek and Roman antiquity, or else consciously modelled on these prototypes. ${ }^{43}$ ) In Renaissance domestic architecture, the revolutionary, wide-scale revival of these ancient forms first occurred in Italy during the latter part of the fifteenth century, making its most dramatic appearance in the countryside, where the construction of hulking feudal fortresses gave way to that of gracious villas whose thinner walls were pierced with large apertures. ${ }^{44}$ Loggias became essential architectural fixtures, sometimes even appearing on all sides of these buildings, to allow the passage of light and air, as well as commanding views onto the landscape. As architectural classicism travelled northward, fuelled by the dissemination of printed Renaissance pattern books, glass allowed builders to inventively adapt these open-air architectural forms for the frigid climates of the north. ${ }^{45}$ Local methods of glazed construction, honed through the development of late-gothic architecture, paradoxically facilitated the adoption of a foreign style.

In the wildest imaginations of northern Europeans, all'antica architecture abounded with impossibly airy arcades suspended on seemingly endless rows of columns, and interior spaces awash with sunlight. Something of the cultural fascination with such structures is expressed in Hans Vredeman de Vries's influential architectural prints, which depict fantastic 
classicizing buildings made up of dramatic networks of galleries, and oddly porous facades that invite unhindered visual access into building interiors (plate 4). ${ }^{46}$ To a significant degree, of course, this was an idealized classicism propagated by images of fictive architecture, among builders who never actually travelled south of the Alps. (As we have seen, though Italian buildings certainly had many more arcaded and terraced spaces, their interiors, which were lit by windows typically covered with oiled cloths rather than glass, were usually dimmer than their northern European counterparts. ${ }^{47}$ ) Vredeman's exaggerated columnar architecture, whose lattice-like openness exceeds the transparency of even its Italian Renaissance models, appears at times almost wilfully out of place amidst his otherwise very Netherlandish-looking cities.

The foreignness of the architecture in these images underlined a discrepancy between style and geographical context that deeply troubled contemporary Dutch and English architectural theorists. The late-sixteenth-century Flemish architect, Simon Stevin, warned, for instance, against adopting a building practice common in Renaissance Italy: "the use of two or three galleries, one above the other" in palace courtyards as means of circulation between buildings and floors. These open structures were "most inconvenient, especially if there is rain, hail or snow," because men of high rank were forced to use them even in inclement weather. To ameliorate such problems, in "many palaces (especially in cold countries) the upper galleries are enclosed with wood or some other shoddy structure of unsightly appearance. ${ }^{\prime 48}$ In his 1631 Architectura Moderna, Salomon de Bray echoed this injunction against the construction of exposed multi-storeyed loggias:

And even if one should also want to make many open galleries on top of each other, and to make entirely porous (doorluchtige) buildings, as was done in the past by the Greeks and also still in Italy, because sweet air and warmth are common there; 
certainly we would consider ourselves deceived, because our cold, heavy wind, rain and snow prohibit this, and would make this unusable, and would lead to premature decay, and thus, though our detriment, [we] would come to a belated realization of our error. $^{49}$

Architectural commentators extended their critique to the problem of fenestration. On this issue, Sir Henry Wotton went so far as to challenge the authority of Vitruvius, whom he deemed "an extreame lover of luminous roomes." While he allowed that "a franke light, can misbecome noe ædifice whatsoeuer," Wotton admonished that "on the other side we must take heede to make a house (though but for civill use) all eyes, like Argus." ${ }^{50}$ Northern European architects were by turns fascinated by and critical of the proliferation of glazed apertures, which left inhabitants vulnerable to both external optical and environmental intrusion.

At the heart of these discourses was a shared recognition of architectural classicism's site-specific nature. De Bray explained that the architect must design with a sensitivity "to the location (gelegentheydt), cold, and warmth of the land," calling on his compatriots to invent a manner of modern building suited to the customs and geography of his country. ${ }^{51}$ In similar terms, Wotton found that architecture must conform not only to ancient models or rules of proportional harmony, but must be suited above all to what he termed the "nature of the region." ${ }^{52}$ Although Vitruvius and his Italian Renaissance followers had laid theoretical groundwork for such discussions - when considering the effects of climate and geography on the selection of building sites and materials, or the disposition of rooms for use in different seasons - they rarely offered practical specifics on building in foreign geographies. ${ }^{53}$ For instance, Palladio praised the graceful form of a low-sloping roofline; yet the preponderance of snow and rain in northern climates forced builders there instead to construct steeply 
pitched roofs, and thus to mar the beauty of their architecture in strict classical terms. ${ }^{54}$ The arrival of all'antica fashions in northern Europe cast into stark relief the impossibility of transplanting the building traditions of a distant place, unless they were first to undergo a profound transformation.

Clear glass therefore played a crucial role in this process of translation, enabling northern builders to visually mimic the breezy, light-suffused structures they associated with Renaissance Italy and the ancient Mediterranean. Its use gave rise to a rich array of ingenious simulated semi-outdoor spaces. Consider the example of Kirby Hall, an English country house from last quarter of the sixteenth century. Viewed in plan, its configuration echoes the much-imitated schemes from Palladio's illustrated architectural treatise. Yet what were loggias in its Italian models have metamorphosed into glassed enfilades (plate 5 and plate 6). Gothic and classical architecture are mutually reinforcing stylistic systems in the courtyard: giant-order Ionic pilasters are interposed between monumental sheets of floor-to-ceiling fenestration (a characteristic feature of the English perpendicular style) to approximate the effect of an open trabeated structure (plate 5). Even structures conceived initially as open spaces often became fully enclosed. For instance, Burghley House's south loggia, built in the second half of the sixteenth century, was converted into a glazed gallery during the subsequent century. ${ }^{55}$

Similar schemes appear in both prestigious civic buildings and the apartments of wellto-do city dwellers. The Bremer Rathaus, for instance, features a central avant-corp consisting of two splendidly fenestrated levels framed within a grid of Doric and Ionic columns, all stacked atop an arcade opening onto the market square. Although the builders rehearsed earlier gothic methods of fenestration, they cunningly disguised the vertical stone mullions as slender minor-order Ionic columns (plate 6). This structure is perhaps a glazed 
spinoff of the famous double-storey Renaissance loggia adjoined a couple decades earlier to the Rathaus in Cologne, a city with close cultural-political ties to Bremen (plate 7). ${ }^{56}$

In the same way, the staircase of Lübeck's Rathaus is a fenestrated equivalent of the covered staircases that abutted many other German town halls (plate 8 and plate 9); stylistically speaking, it may even have drawn inspiration from uncovered Italian models, such as the monumental Scala dei Giganti of the Palazzo Ducale in Venice. ${ }^{57}$ The urban homes of wealthy merchants also borrowed this syntax of superimposed classical orders flanking windows of impressive size (plate 10). All the fenestration enumerated above consist of masonry frameworks derived from gothic construction; yet the frameworks are mostly shorn of the ornate tracery or decorative leading that characterized late gothic architecture, and are instead streamlined into grids that allow visual attention to focus on the adjacent classical orders, rather than the glazing itself. When filled in with colourless glass Hendrick Stevin recommended panes "that give such clear light that everything is as perfectly visible through them as if there were no glass at all" ${ }^{58}$ - the minimalist fenestration acted as placeholders for the open spaces found in classical intercolumniation.

For much of the early modern period, moreover, there persisted a considerable ambiguity between the designation of certain glazed and open-air structures, which attested to their status in the cultural imagination as analogous forms of architecture. Architectural appendages such as the Lübeck staircase or the avant-corp of Bremen's Rathaus did not fall neatly into binary categories of open or closed, since they derived from prototypes that were roofed and attached to larger enclosures, yet nevertheless were porous and extended out of (and were therefore partly externalized from) the main body of the building. Even when they became fully enclosed with glass, such liminal structures continued to bear associations with their earlier, more open models. 
Such was the case of the oriel, an architectural element nowadays defined as a projecting bay window suspended above the ground, which came into common use in the early modern period. During the fifteenth and sixteenth centuries, the English term 'oriel' (as well as its Dutch and German equivalent, Erker) could also encompass a variety of outdoor or partially outdoor structures, including balconies, porches, galleries, and the defensive perches of fortified structures. ${ }^{59}$ More specifically, it often referred in this period to an upperlevel threshold space, such as a balcony, porch, or antechamber situated at the head of a staircase or outside the raised entrance to a building. ${ }^{60}$ (Interestingly, the Lübeck staircase could be seen to merge all these senses of the term.) Even as the word's present meaning began to crystallize, such semantic multivalence continued to symptomize the cultural understanding of this window typology, for the glazed oriel increasingly served in the early modern period as an ersatz terrace or balcony (plate 11). ${ }^{61}$

In the spirit of its typological hybridity, early modern builders strove to endow this pendent window with all the apparent weightlessness and openness of a balcony. Despite its susceptibility to decay, timber often prevailed over masonry as the building material of choice for the oriel, since its lightweight construction allowed the window to cantilever as dramatically as possible without the support of massive corbeling or unsightly pillars. ${ }^{62}$ By the seventeenth century, the quest to achieve this floating effect eventually led to the development of slender and more durable iron frameworks, which further dematerialized the window frame, enhancing the oriel's overall transparency. ${ }^{63}$ Such minimalist construction proved especially useful for purposes of architectural adaptation, since it enabled the insertion of overhanging fenestration into existing buildings without unduly straining weak walls, or blocking light to windows below. ${ }^{64}$ When fitted with all'antica consoles or decorative plastering, the sills of oriel windows resembled the parapets of Italianate balconies. Such kijckveinsters (or viewing windows) offered a protected environment that 
simulated the experience of seeing outdoors. As Hendrick Stevin explained, a person could "look out in rainy weather without getting wet, or in windy and freezing weather without the room getting cold." ${ }^{\prime 65}$ The French architectural commentator, Louis Savot, extolled the advantages of this unencumbered panoramic view, "not only in front, but also on the sides and below." ${ }^{66}$ Recommending to his countrymen an architectural feature he believed to be found "principally in Germany," Savot evidenced a receptiveness toward northern vernacular typologies that paralleled his interest in Italianate classicism.

A similar polysemy marked the term 'gallery,' which was interchangeably used in the Renaissance to describe both open loggias, as well as long glazed spaces that were purposebuilt for walking between rooms. ${ }^{67}$ Jacques Androuet du Cerceau called all such forms of architectural circulation "galleries," specifying some as "arcuated" (à arcs) and others as "fenestrated" (à croisées), depending on their degree of enclosure. ${ }^{68}$ Others drew geographic distinctions in their manner of construction. ${ }^{69}$ Sebastiano Serlio described the enclosed galleries he found throughout France as "windowed loggia[s]." to Italian readers an architectural feature still relatively unknown in southern Europe. While it originally encompassed a fluid set of definitions, the fenestrated gallery eventually crystallized into a distinct typology: the light-filled corridors, often richly appointed with painting and sculpture, which witnessed their fullest development in the palaces of baroque France. In time, these stately spaces would provide the permanent architectural alternative to the makeshift wooden enclosures formerly constructed (as Simon Stevin explained) to protect the exposed upper-level loggias of Renaissance palaces. In this respect, the gallery's development should not be considered in isolation. It belonged to a loose class of other early modern architectural innovations, which were ingenious compromises between the constraints of environment, habitability, and the competing cultural quest for ever-greater architectural illumination. 
These novel typologies defy any common sense understanding of architectural vernacularism. They illustrate the paradox that local innovation found stimulation in the desire to recreate the foreign. Indeed, the arrival of Italianate styles accelerated developments already underway in the late gothic architecture of northern Europe, which had pioneered the unprecedented use of glass and the dematerialization of the wall. The gothic in this sense was not a stylistic antithesis of architectural classicism, but a necessary precondition for recreating the architecture of another time and place. While to our modern eyes the great fenestrated structures built around 1600 may not appear properly 'classical' in comparison to the restrained Palladian orthodoxy that developed later in the seventeenth century, for contemporaries their luminous interiors came as close as it got to experiencing remotely the Mediterranean environments that northern Europeans craved. ${ }^{71}$

\section{Urban Optics}

While external forces of regional climate shaped the proliferation of glazed fenestration, its most significant effects were felt inside buildings. For this reason, the influence of climate by itself does not sufficiently explain the newfound demand for the material among populations whose reality had been conditioned for centuries, in the words of Lucien Febvre, by an existence in the "still, silent, dark cold of heatless dwellings."72 Glass's primary function was the enhancement of interior illumination, and its growing use coincided with socio-cultural changes in early modern Europe that had made the indoors an increasingly significant locus of human life. Along with this experiential shift, from conditions of sensory privation to visibility in interior spaces, there emerged new, culturally specific modes of perception that manifested themselves in the visual arts and the empirical sciences. To account for the full spectrum of glass's significance in the early modern period, we must therefore draw into our analysis the dynamics of cultural, as well as natural, geography. 
On a cultural level, the most critical driving force behind the demand for glass was the dramatic growth of northern European cities beginning in the second half of the sixteenth century. ${ }^{73}$ As Hans Vredeman de Vries observed, the distinct traditions of fenestration in Italian and Dutch architecture stemmed from divergent, regionally specific patterns of urbanism. Architecture in the "antique, Italian manner" lacked mullioned windows (fenestres croisées), that is, windows designed to hold glass. This is because such buildings, de Vries believed, were generally "without great demand for illumination," since their low height, relatively spacious configuration, and placement on ample sites already provided their interiors sufficient access to sunlight. ${ }^{74}$ By contrast, light was at a premium in the Low Countries, "especially in the great mercantile cities, where spaces are small and very costly." Packed one against the other on deep and narrow plots, townhouses often lay in the shadow of taller neighbouring structures. ${ }^{75}$ As a result, the buildings in these densely constructed cities competed for height, each hoping to capture "the greatest convenience of having illumination [pour en avoir la clarté]."

Transparent glazing functioned in these conditions as a kind of ambient infrastructure. By maximizing the daylight entering these cramped interiors, it helped ameliorate the pressing problem of habitability in overcrowded cities. In this regard, the material's mounting use attended the spectacular socio-spatial changes taking place in early modern northern Europe. ${ }^{76}$ Furthermore, by enhancing interior visibility and extending its duration during the daytime, glass advanced a broadening array of productive activity among a growing population of urban dwellers. This technology of illumination not only aided scholarly study, but also the labour in industrial workshops, the clerical precision required for commercial affairs, and the meticulous conduct of domestic duties. ${ }^{77}$ Interior luminosity, in the last instance, surely fuelled the well-known Dutch obsession with cleanliness. ${ }^{78}$ Painted domestic scenes celebrated this cardinal virtue in the urban household, meticulously recreating the 
sunlight that poured from transparent glass windows, scattering off whitewashed walls and brilliantly bleached linens, reflecting from scrubbed and polished surfaces, exposing each fleck of grime that had to be expunged.

The rising demand for glass in cities, then, signalled an intensified consciousness of light as a precious commodity, which, in turn, also animated the artistic imaginary. A comparison between the work of seventeenth-century architects and painters in the Netherlands, where this sensibility was perhaps most sharply honed, begins to suggest how a shared spatial conception of light governed both the building and visual arts. ${ }^{79}$ (Such a comparison would bring greater historical precision to Wolfgang Schöne's ambitious attempt to chart a modern sensibility of illumination and its pictorial representation.) In his unpublished architectural treatise De Huysbou, written sometime around 1600, Simon Stevin devised an ingenious system for optimizing the interior illumination of residences of various sizes, from roomy palaces to compact urban apartments. ${ }^{80}$ The absence of any systematic method for the lighting of domestic interiors, he noted, had resulted in the design of spaces "so dark that often the midday meal is eaten by the light of a candle." 81 To remedy this defect, Stevin offered for the first time a "general rule of unimpeded light," a kind of spatial algorithm that would prevent any particular room from being hemmed in on all sides by other rooms. ${ }^{82}$ Apart from those facing the street, every room would have a fenestrated wall that opened onto a light well, which would provide illumination for even the humblest everyday activities. On his idealized floor plans of various residences, the light wells or courtyards (lichtplaetsen, literally “air spaces”) appear as the architecture's compositional cores - spatial anchors around which cluster all other parts of the home (plate 12).

This unprecedented concern, with the schematization of architectural light, found striking resonances several decades later in painterly representations. In seventeenth-century Dutch domestic scenes, such as those of Gabriel Metsu, Johannes Vermeer, Nicholaes Maes, 
Jacob Ochtervelt, and Pieter de Hooch, human bodies (instead of rooms) gather around glazed windows. The light sources in these images act as visual focal points and social condensers, places where enhanced visibility facilitates the quotidian activities of reading and writing, sewing, music making, or card playing. As if in adherence to a different sort of spatial-pictorial order, these scenes maintain the concentric arrangement of figures around light sources to such a strict degree that they sometimes even contradict traditional principles of narrative legibility. ${ }^{83}$ In de Hooch's Card Players in a Sunlit Room, for instance, some figures are oriented with their backs toward the viewer, while another is set in contre-jour conditions that leave his entire face in shadow (plate 13). In turn, the visual attention of the figures toward the window echoes the viewer's own relationship to the image itself. ${ }^{84}$ The floor plans in Stevin's Huysbou are diagrammatic embodiments of the same compositional logic.

The luminous spaces represented in these various visual forms were spatial figurations of an idealized domesticity not always realized in practice. ${ }^{85}$ In painted interior scenes, apertures choreographed optical itineraries through rooms and courtyards to reveal the workings of the pristine, well-ordered household ${ }^{86}$ Glass windows reinforced this iconography, illuminating the physical and moral purity that was to pervade all spheres of social life. (Alternatively, the windows in these moralizing pictures could also cast a less flattering light on instances of depravity and human folly, which inevitably unfolded in these spaces as well.) In much the same way, Stevin's designs crystallized an ideal mode of domestic organization, whereby light would reach every corner of the home.

The cultural concern manifested in these works, with achieving optical mastery over the (built) environment, paralleled the rise of a scientific culture keen to discern the properties of light, and methods to artificially extend the capacities of human vision. ${ }^{87}$ In the late Renaissance, naturalists increasingly sought to understand the geometry of light's 
radiation and refraction through glass spheres, spectacles, and apertures; occasionally such insights crossed into the domain of architecture, and vice versa, as theorists categorized the varying intensities of interior illumination that could be achieved with different configurations of fenestration. ${ }^{88}$ Such was the case with the polymath Isaac Beeckman, a student of Simon Stevin and a commentator on the latter's Huysbou. ${ }^{89}$ The architecture of everyday life served as Beekman's observational laboratories. He installed polished glass lenses, ground into different shapes, into the windows of his study; he recorded the light patterns projecting from the leaded window lattices of his privy chamber; he noted the optical illusions created by the mullions of church windows. ${ }^{90}$ The loose exchanges between the building and optical sciences offer an intellectual context for understanding the interior scenes of Dutch painters, which catalogued sunlight's manifold behaviours through apertures and mediums - as it passes through and reflects off the material imperfections of glass windows, projects geometric patterns directly onto architectural surfaces, then indirectly illuminates adjacent objects, scattering shadows in multiple directions (plate 14). ${ }^{91}$

In this regard, the glass windows that appear in early modern paintings - to say nothing

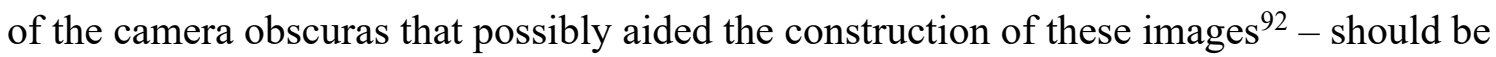
considered sophisticated optical instruments in their own right. Through the course of the seventeenth century, the window became a significant site of architectural innovation, as French, Dutch, and English builders phased out the gothic practice of fixing glazed panes in masonry frames, and devised in its place all manner of mobile fenestration: inward-swinging glass casements, framed in iron or wood, eventually without mullions that would block the passage of light; and, by mid-century, sash windows with vertically or horizontally sliding panes (plate 15). ${ }^{93}$ The moving parts were controlled by finely crafted iron hardware, such as spring catches and swivelling turnbuckles, counterweighted pulleys, hinges, handles, and hooked stays (plate 16). Coupled with interior shutters and blinds, these environmental 
mediators allowed a building's inhabitants to precisely calibrate ventilation, luminosity, and visual permeability. ${ }^{94}$ When set within the undulating forms and gem-like geometries of jettied fronts, these animated architectural elements charged the facade with a kind of kinetic energy (plate 17). Not unlike the spectacles and telescopes necessary for scientific study, then, windows in the early modern period became mechanical contraptions of glass and metal that augmented visibility and controlled sensory perception.

While it would be reductive to draw a one-on-one correlation between architecture and the early modern sciences, the practice of both undeniably belonged to a common cultural ambit. Whether for the housewife or the experimentalist, the proliferation of glass windows served societies that increasingly regarded interior illumination (and thus interior vision) an essential medium of quotidian life. And the refinement of these windows into architectural prostheses, which could effectively manage environmental resources such as light and air, paralleled an increasingly instrumental view of natural philosophy as a mode of knowledge that could maximize the practical utility of nature.

\section{Early Modern Glass and its Environmental Discontents}

Our discussion so far suggests that the early modern use of window glazing was a practice responsive to the twin demands of natural and cultural geography. This analysis might seem at first to confirm the recent conclusions of one scholar, who describes the lantern houses of the Elizabethan period as architectural solutions that deftly navigated cultural needs and environmental constraints, seamlessly integrating human habitation within its natural context. ${ }^{95}$ Yet the reality was far more complicated. The builders of human habitations often struggled to overcome - not just to exist harmoniously with - the inevitable constraints of topography, climate, and other pre-existing site conditions. Especially in matters of its facture, window glazing was an environmentally invasive architectural practice, which 
simultaneously also subjected building interiors to greater intrusion from the natural environment.

On the one hand, this sheer barrier exacerbated architecture's vulnerability to the vagaries of the weather. Windows are among the most porous parts of a building's exterior envelope, and even with modern advances in weatherproofing they pose considerable problems for the control of interior climate. This was all the more true in the sixteenth and seventeenth centuries. For the glass window, as Sir Henry Wotton explained, was a delicate assemblage of such "unsociable pieces, as wood, iron, leade, and glasse." ${ }^{96}$ Before their substitution with sturdy timber muntins, slender lead cames served in medieval and Renaissance windows to hold together the glass panes. The window's inherent structural weakness was further exacerbated when glaziers cut corners with shoddy leading and overly thin panes. Moreover, with changes of heat or moisture in the surrounding environment, the window's multiplicity of "unsociable" organic and synthetic elements would swell and shrink, absorb moisture, freeze, and dry, rot and rust, at varying rates. As a result of this material incompatibility, fenestration developed holes and came apart, as wood split, stone cracked, and glass quarrels became dislodged from their lead surrounds.

Paradoxically, then, these fragile barriers often exposed inhabitants to the very weather conditions they were supposed to keep out. Erasmus complained that in the rooms of great houses, enormous glazed walls failed their function "to admit the light and exclude the wind," since they "are full of chinks through which enters a percolated air." Whatever health benefits might arise from walking in these protected spaces were quickly obviated, according to his citation of Galenic medical theory, by stagnating draughts "more noxious than the wind." 97 Simon Stevin similarly explained that between wooden window frames and their surrounding brick apertures there often appeared gaps "an inch or more wide, allowing draughts and cold to enter. $" 98$ The problem was exacerbated when aristocrats, in order to 
enjoy the spectacular prospects afforded by their immense windows, placed their great houses on elevated sites most exposed to the "cold and stormy blastes of winter." 99 In the event of a great storm, when they were "exposed to all violence of weather," glass windows would shatter altogether. ${ }^{100}$ A sudden "tempest of hail, wind, thunder, and lighting," according to John Evelyn, "broke all glass about London."101

To combat the cold in these draughty interiors, builders supplemented their architecture with compensatory features. Although the windows of great houses opened onto stunning views, in practice these prospects were often obscured by heavy curtains, layered with multiple coverlets, which kept out the cold. ${ }^{102}$ Fenestration also necessitated heating, in addition to weatherproofing. The dramatic roofscapes of Renaissance residences, upon which sprouted dense forests of chimneys, must have correlated directly with the proliferation of leaky glass facades in northern Renaissance architecture (plate 18). Nearly each of Hardwick Hall's roughly thirty rooms had at least one fireplace - a sharp contrast to the great Renaissance ducal palace in Urbino, whose 240 rooms were heated by only forty fireplaces. ${ }^{103}$ While such architectural accessories certainly added splendour to the buildings, they were also the costly by-products of their builders' architectural ambitions.

On the other hand, if glazed fenestration subjected human habitation to the intrusion of the elements, its production also ravaged the natural environment. Even as early modern writers extolled glass's ability to visually engage occupants with the outdoors, they were also painfully aware of glass manufacturing's ecological consequences. Before the widespread use of coal furnaces, as well as the systematic state-sponsored practice of forestry, the industrial production of glass and iron required the clearing of entire forests for fuel. ${ }^{104}$ More wood, of course, then had to be burned to warm the chilly domestic spaces fenestrated with this glass. The apparent shortage of wood grew acute in a period of commercial and geographic expansion, as the same northern maritime powers where builders demanded glass also relied 
increasingly on timber for the expansion of their naval and merchant fleets. Glass manufacture pitted state and local interests, and led to mass deforestation between the latesixteenth and eighteenth centuries. ${ }^{105}$ For this reason, early modern sovereigns constantly attempted to stem the industrial destruction of timber, either by mandating the adoption of coal-burning technology, or by outright limiting the production of glass. ${ }^{106}$ While the skeletal glazed buildings of the Renaissance appear to dissolve into pure geometry, they were cases not of metaphysical abstraction, but of material excess. One early modern land surveyor put the situation bluntly: "Glass houses, great woods wasted."107

Having traced this vexed environmental history of early modern architectural glass, we might find the material's most recent manifestation in architectural modernism to be both more and less familiar. Viewed over the longue durée, on the one hand, it seems natural that the peculiar fascination with architectural transparency in the last two centuries should first take form in Germany, France, England, and the Netherlands. Such developments were embedded in a longer process of industrial and aesthetic refinements, stretching back to at least the Renaissance, which had unfolded in these very geographic locales. Perhaps something of the northern Renaissance mastery with adapting glass to all'antica geometries has unexpectedly re-emerged in modernist buildings, whose calm proportions and transparent Miesian grids exhibit a streamlined crypto-classicist sensibility. Furthermore, the ever-greater demand for interior illumination in early modern secular architecture, which was so necessary for ensuring productivity in proto-capitalist societies, prefigured in the ubiquitous electric lighting in our own time. And earlier anxieties over the ravenous use of wood have anticipated the unsustainable fuel consumption that has attended our path to modernity. Plotted in this way, the histories of early modern and modernist architecture appear merely as different stages in the same developmental trajectory. 
Yet the culmination of these developments in modernist architecture has, paradoxically, also inverted the experiential and environmental logic of their early modern precedents. Whereas the geographic vectors of Renaissance classicism radiated outward from southern Europe, the triumph of architectural modernism has flung a northern building paradigm to sweltering deserts and jungles in all corners of the globe. To take only one example, the construction of Sir Norman Foster's celebrated airport in Hong Kong is an act of (environmental) colonialism tantamount to building an English greenhouse in the semitropical city. Under such climatic conditions, simply heating these vast glazed structures in winter is not enough; we must now also cool and dehumidify them the rest of the year, multiplying the architecture's fuel consumption many times. If early modern fenestration rendered occupants highly sensitive to the changeable conditions of their natural surroundings, the stylistic homogeneity of contemporary glass buildings, coupled with electric lighting and mechanical systems of climate control, has instead all but obliterated experiential distinctions between day and night, the rhythms of the seasons, and the vagaries of the weather. ${ }^{108}$

In comparison to the unprecedented spatial-temporal placelessness of contemporary architecture, even the radically increased early modern production and use of window glass appear highly attuned to local ecologies. Perhaps, then, the vernacular qualities of architectural glazing in early modern northern Europe are only notable to us retrospectively. In this respect, this architecture's site-specificity is not just a fixed descriptive category, but also an effect of our subjective distance (historical or geographical) from our object of analysis. Such shifting and seemingly incommensurable vantage points embody what I have identified in this essay as the synthetic vernacularism of early modern glazed architecture an architecture that alternately seems to exemplify the regional traditions of a bygone era, yet also to presage the environmental illogic of the building practices in our own day. 
Notes

An earlier version of this essay was presented in April 2011, in the panel 'Materials, Matter, Materiality, and Architecture' chaired by Dr. Margaretta M. Lovell at the Society of Architectural Historians Annual Meeting in New Orleans. I am grateful to Professor Lovell, as well as Christy Anderson, Robert Bork, Bruno Klein, Kurt Klein, Alina Payne, Hermann Schlimme, Freek Schmidt, and the two anonymous reviewers for their keen insights and help. My research has benefited from the generous support of the Samuel H. Kress Foundation and the Bibliotheca Hertziana - Max-Planck-Institut für Kunstgeschichte in Rome.

${ }^{1}$ Francis Bacon, Of Building, in The Works of Francis Bacon, eds James Spedding, Robert Leslie Ellis and Douglas Denon Heath, 7 vols, London, 6, 484.

${ }^{2}$ The canonical (and now much revised and contested) accounts are: Henry Russell Hitchcock and Philip Johnson, The International Style: Architecture Since 1922, New York, 1932; Nikolaus Pevsner, Pioneers of the Modern Movement from William Morris to Walter Gropius, London, 1936; Sigfried Giedion, Space, Time and Architecture: The Growth of a New Tradition, Cambridge, MA, 1941.

${ }^{3}$ Kenneth Frampton, 'Towards a Critical Regionalism: Six Points for an Architecture of Resistance', The AntiAesthetic: Essays on Postmodern Culture, Port Townsend, 1983, 26.

${ }^{4}$ For one account of this transition, see Denis Woronoff, 'Quand l'exception devient la règle: remarques sur le vitrage en France, XVIe-XVIII siècles', Verre et fenêtre, de l'Antiquité au XVIIIe siècle, Paris, 2009, 133-5.

${ }^{5}$ Adam Smith, An Inquiry into the Nature and Causes of the Wealth of Nations, 2 vols, Oxford, 1976, 1, 23.

${ }^{6}$ Sir Henry Wotton, The Elements of Architecture, Collected by Henry Wotton Knight, from the Best Authors and Examples, London, 1624, 55.

${ }^{7}$ As Catherine Hess and Timothy Husband explain, “an excavated glass may have been a local product or an import from a distant manufacturer. Even glasses excavated at major production sites...can, at best, indicate one probable source of glasses that can be found elsewhere in identical form. This is because no glasshouse seems to have enjoyed, so to speak, copyright protection." Catherine Hess and Timothy Husband, European Glass in the J. Paul Getty Museum, Los Angeles, 1997, 25.

${ }^{8}$ For this reason, "Normandy glass" was so called long after it was actually made in Normandy, and glass $\grave{a}$ la façon de Venise was produced all over early modern Europe once the republic's carefully-guarded technologies 
and formulas could be successfully approximated elsewhere. On "Normandy glass" as a synonym for "crown glass", see the entry 'Glass' in Encyclopaedia Britannica, 29 vols, New York, 1910, 11, 104. On Venetian-style glass, see Johan Veeckman and Sarah Jennings, eds, Majolica and Glass from Italy to Antwerp and Beyond: The Transfer of Technology in the 16th and Early 17th Century, Antwerp, 2002; Jutta-Annette Page and Ignasi Doménech, Beyond Venice: Glass in Venetian Style, 1500-1750, Corning, 2004.

${ }^{9}$ The historiography of this nineteenth-century analytical framework and its relation to nationalism is discussed in chapter 2, 'The formulation of a geography of art' in Thomas DaCosta Kaufman, Toward a Geography of Art, Chicago, 2004, 43-67.

${ }^{10}$ See, for instance, the essays in Thomas DaCosta Kaufmann and Elizabeth Pilliod, eds, Time and Place: The Geohistory of Art, Aldershot, 2005. An excellent recent study of the Renaissance discourse on geography and style is David Young Kim, The Traveling Artist in the Italian Renaissance: Geography, Mobility, and Style, New Haven, 2014.

${ }^{11}$ On the use of such windows in domestic spaces, see Peter Thornton, Seventeenth-Century Interior Decoration in England, France, and Holland, New Haven, 1978, 80-1.

${ }^{12}$ Rudolf Stein, Romanische, Gotische und Renaissance Baukunst in Bremen, Bremen, 1961, 534-8.

${ }^{13}$ On the geographical spread of this architecture, see Juliette Roding, 'The North Sea Coasts, An Architectural Unity?', The North Sea and Culture (1550-1800): Proceedings of the International Conference held at Leiden, 21-22 April 1995, eds Juliette Roding and Lex Heerma van Voss, Hilversum, 1996, 96-106.

${ }^{14}$ Mark Girouard, Elizabethan Architecture: Its Rise and Fall, 1540-1640, New Haven, 2009, 258.

${ }^{15}$ Philippe Michel, 'Chantier ou atelier: aspects de la verrerie normande aux XIVe et XVe siècles', Annales de Normandie, 42: 3, 1992, 239-57; Michel Philippe, Naissance de la verrerie moderne: XIIe-XVIe siècles: aspects économiques, techniques et humains, Turnhout, 1998.

${ }^{16}$ On the higher esteem for Normandy glass over that of other regions, see Yvette Vanden Bemden, 'Le métier de verrier à la fin du Moyen Age et au début de la Renaissance dans les anciens Pays-Bas', Österreichische Zeitschrift für Kunst und Denkmalpflege, 54: 2/3, 2000, 380-81; Richard Marks, Stained Glass in England During the Middle Ages, Toronto, 1993, 30-1; Richard Marks, 'Window glass', in English Medieval Industries: Craftsmen, Techniques, Products, eds John Blair and Nigel Ramsay, London, 1991, 266-7.

${ }^{17}$ Franz Adrian Dreier, Glaskunst in Hessen-Kassel, Kassel, 1969. 'Germany VII: Glass' in The Grove Encyclopedia of Medieval Art and Architecture, Oxford, 2012, 677-8. 
${ }^{18}$ On the distribution of wares from Antwerp, Bruges, and Rouen, see John A. Knowles, 'Processes and methods of the mediaeval glass painters', Journal of the Society of Glass Technology, 6, 1922, 257; On ports of arrival in England, see above, and Marks, Stained Glass in England, 30-1; On Hessian glass in Bremen, B. Dubbe, 'Hessische Glasexport naar Nederland', Bulletin van de Nederlandse Oudheidkundige Bond, 15: 4, September 1962, 299-310.

${ }^{19}$ Eleanor Smith Godfrey, The Development of English Glassmaking, 1560-1640, Oxford, 1975; Robert Jesse Charleston, English glass and the glass used in England, circa 400-1940, London, 1984, 42-108.

20 “Di questa arte hanno lavorato meglio i fiaminghi et i franzesi che l'altre nazioni....Vero è che per condurle che elle siano tali, bisognano primieramente tre cose: cioè una luminosa trasparenza ne' vetri scelti, un bellissimo componimento di ciò che vi si lavora, et un colorito aperto senza alcuna confusione. La trasparenza consiste nel saper fare elezione di vetri che siano lucidi per se stessi, et in ciò meglio sono i franzesi, fiaminghi et inghilesi che i veniziani: perché i fiaminghi sono molto chiari et i veniziani molto carichi di colore, e quegli che son chiari, adombrandoli di scuro, non pèrdono il lume del tutto tale che e' non traspaino nell'ombre loro...." Giorgio Vasari, Le vite de' più eccellenti pittori, scultori e architettori, 2 vols, Florence, 1568, 1, 61-2. ${ }^{21}$ In Florence prior to the mid-sixteenth century, members of the Jesuate order were often commissioned as prestigious glaziers. But Vasari compares their skill unfavourably with the work of Marcillat, discussing their defacement of one of Marcillat's works in Santa Felicità: “la quale finestra venne nelle mani de' frati Gesuati, che in Fiorenza lavorano di tal mestiere, et essi la scommessero tutta per vedere i modi di quello, e molti pezzi per saggi ne levarono e di nuovo vi rimessero, e finalmente la mutarono di quel ch'ella era." Vasari, 2, 94. For the prior work of the Jesuates in the Palazzo Vecchio, see the ricordi of Pierfrancesco Riccio: "Fecesi pagare al Tasso legnaiuolo scudi X d'oro moneta dal depositario delle bande e scudi 4 dal detto a Battista m.o di vetriate per le finestre della sala della cappella di Palazzo con ordine di Michel Ruberti..." (November 1542); and "Feci una poliza a Michel Ruberti che pagasse scudi II d'oro moneta alli frati injesuati per havere rassettate le fenestre di vetro del Palazzo Ducale.” (11 October 1544). These transcriptions are available online at: http://documents.medici.org ${ }^{22}$ Giuseppe Marchini, Le vetrate italiane, Milan, 1956, 56-7, 232; Giuseppe Bacchi, La Certosa di Firenze, Florence, 1930, 113-6; Andrea Gáldy, 'The Scrittoio della Calliope in the Palazzo Vecchio: A Tuscan museum', Renaissance Studies, 19: 5, November 2005, 699-709.

${ }^{23}$ The distinction made in French between grosses and petites verreries indicates that the manufacture of flat glass, and small-scale objects required different artisanal expertise and equipment. Philippe, Naissance de la 
verrerie, 155-84; Godfrey, Development of English Glassmaking, 7-9; Warren Candler Scoville, Capitalism and French Glassmaking, 1640-1789, New York, 1968, 8.

${ }^{24}$ Spanish and Italian gothic buildings had considerably smaller windows, for instance, than their French, Netherlandish, English, and German counterparts. My thanks to Dr. Robert Bork for drawing my attention to this phenomenon.

${ }^{25}$ Cardinal Aeneas Silvius Piccolomini (later Pope Pius II) noted that in Bohemia, “...fenestre alte atque amplissime conspicuo vitro et admirabili opere lucem prebebant. Neque hec tantum in oppidis atque urbibus, sed in villis quoque admirari licebat.” Pius II (Aeneas Silvius Piccolomini), Historia Bohemica, eds Joseph Hejnic and Hans Rothe, 3 vols, Cologne, 2005, 1, 254. He also admired a gothic chapel cathedral of York "whose glass walls are held together by the slenderest columns," and famously modelled his own architectural commissions on the luminous Hallenkirchen of southern Germany. On the cathedral of York, see Pius II, Commentaries, trans Margaret Meserve and Marcello Simonetta, 2 vols, Cambridge, MA, 2004, 1, 24. A classic study on the influence of Hallenkirchen on the pope is Ludwig Heinrich Heydenreich, 'Pius II. als Bauherr von Pienza', Zeitschrift für Kunstgeschichte, 6: 2/3, 1937, 105-46.

26 “...les fenêtres sont fermées, non par des bannes, mais par de belles vitres, dont on voit un grand nombre." Francesco Gregory D’Ierni, 'Description de Paris', trans. Gaston Raynaud, Bulletin de la Société de l'histoire de Paris et de l'Ile-de-France, 12, 1885, 166.

27 “Leurs chambres à faute de vitres \& closture des fenestres, moins propres qu'en France.” Michel de Montaigne, CEuvres complètes, eds Albert Thibaudet and Maurice Rat, Paris, 1188.

${ }^{28}$ Gilbert Burnet, Some Letters, Containing an Account of what Seemed Most Remarkable in Switzerland, Italy, \&c., Rotterdam, 1686, 115.

${ }^{29}$ Such methodological issues and barriers to research are discussed in the introduction to Marta AjmarWollheim and Flora Dennis, eds, At Home in Renaissance Italy, London, 2006, 10-32.

${ }^{30}$ Woronoff, 'Quand l'exception devient (presque) la règle'.

${ }^{31}$ After a legal dispute between a lessee who had installed glass into the windows of the lessor's house, it was established in England that glass "is parcel of the house, and shall descend as parcel of the inheritance to the heir, and that the executors should not have them...glass annexed to windows by nails, or in other manner, by the lessor or by the lessee, could not be removed by the lessee, for without glass it is no perfect house." The Reports of Sir Edward Coke, eds John Henry Thomas and John Farquhar Fraser, 6 vols, London, 1826), 2, 447- 
8. For the broader architectural context, see Matthew Johnson, English Houses, 1300-1800: Vernacular Architecture, Social Life, Harlow, 2010, 100.

${ }^{32}$ See chapter 2, 'Craftsmen, artists and their professional organisation' in Joost M. A. Caen, The Production of Stained Glass in the County of Flanders and the Duchy of Brabant from the XVth to the XVIIIth Centuries: Materials and Techniques, Turnhout, 2009, 95-116.

${ }^{33}$ In her survey on stained glass, a chief authority on the topic writes that by the late sixteenth and early seventeenth centuries, "[there] had been too long a hiatus since the monumental installations of the early sixteenth century for glass to be seen as truly important art." She does not pick up the narrative until many centuries later, in "a period that equaled the output of the Renaissance: the stained-glass revival of the nineteenth century." Virginia Chieffo Raguin, Stained Glass: From Its Origins to the Present, New York, 2003, $167-8$.

${ }^{34}$ The bias for figuration and iconography is evident in books on stained glass that show as many images of preparatory cartoons - i.e. 'master' drawings not actually executed by the glaziers - as windows themselves. See for instance, Timothy B. Husband, Ilja M. Veldman, Ellen Konowitz and Zsuzsanna van Ruyven-Zeman, The Luminous Image: Painted Glass Roundels in the Lowlands, 1480-1560, New York, 1995. One scholar even demotes Renaissance glaziers to mere 'craftsmen', distinguishing them from the 'artists' who 'produced designs only'. Virginia Chieffo Raguin, Northern Renaissance Stained Glass: Continuity and Transformations, Worcester, MA, 1987, 10. 35 “...la tecnica del vetro è andata gradatamente scomparendo durante il Rinascimento, che richiedeva chiarezza di illuminazione ambientale, fino a far perdere ogni uso di manipolazione di vetri colorati e di pitture"; "scade in una mortificante mediocrità del tutto anonima"; "stadio di barbarie bruta." Marchini, Le vetrate, 11-2, 56.

${ }^{36}$ For an analysis of the narrative logic underlying Vasari's periodization, see Alina Payne, 'Vasari, Architecture, and the Origins of Historicizing Art', RES: Anthropology and Aesthetics, 40, 2001, 51-76. ${ }^{37}$ Vasari, Vite, 2, 61. On the use of glass in ancient Roman windows, see Francesca Dell'Acqua, 'Le finestre invetriate nell'antichità romana', in Vitrum: il vetro fra arte e scienza nel mondo romano, eds Marco Beretta and Giovanni Di Pasquale, Florence, 2004, 109-19; Thea Elisabeth Haevernick and Paula Hahn-Weinheimer, 'Untersuchungen römischer Fenstergläser', Saalburg-Jahrbuch, 14, 1955, 65-73.

38 “...hanno poi imaginato gli artefici fare un musaico de le figure di questi vetri, diversamente colorati e commessi ad uso di pittura." Vasari, Vite, 2, 61. 
${ }^{39}$ In his biography of Marcillat, Vasari explains that the glazier "faceva figure di colorito non meno unite che se elle fossero d'una vaghissima et unitissima pittura a olio." Marcillat's knowledge of drawing and composition was acquired in high Renaissance Rome: "Non aveva Guglielmo quando prima arivò a Roma, se bene era pratico nell'altre cose, molto disegno; ma conosciuto il bisogno, se bene era in là con gl'anni, si diede a disegnare e studiare, e così a poco a poco lo migliorò...." Vasari, Vite, 2, 91-2.

40 “...als ob hinter den Fenstern das Tageslicht zu ahnen sei.” Wolfgang Schöne, Über das Licht in der Malerei, Berlin, 1954, 101.

41 "Da die Glasmalerie als Kunstgattung ebenso wie der Goldgrund...ist mit dem Auftreten des Beleuchtungslichts ihr Schicksal besiegelt.” Schöne, Über das Licht, 101.

${ }^{42}$ Schöne's argument is largely reiterated in Hans Belting, Bild und Kult: Eine Geschichte des Bildes vor dem Zeitalter der Kunst, Munich, 1990.

${ }^{43}$ In the English language, portico and porticus seem to have first appeared in the late sixteenth and early seventeenth centuries, when they are used in historical terms to designate an ancient Greek stoa (a covered colonnaded public walkway from Greek antiquity), or similar Roman structure (such as the Porticus Octaviae); or a specifically Italian colonnade of this kind (such as those of Venice's Procuratie). Later in the seventeenth century, the words gain currency as a term for a classical columnar temple front, whether attached to a pagan cult building or a classicizing Christian church, such as Saint Paul's Cathedral in London. Examples may be found in Oxford English Dictionary, 3rd ed., 2006, s.v. 'portico' and 'porticus'. As late as the eighteenth century, Jacques-François Blondel explained that the early modern long gallery was a latter-day manifestation of the porticus (i.e. stoa): “Gallerie, en latin Porticus, s'entend d'un lieu couvert, mais percé d'arcades....Les Galleries comme nous l'entendons, sont des pieces intérieures décorées avec magnificence." Quoted in Claude Mignot, 'La galerie dans les traités', in Les grandes galeries européennes, eds Claire Constans and Mathieu Da Vinha, Paris, 2010, 39.

${ }^{44}$ On this shift, see especially chapter 3 of James Ackerman, The Villa: Form and Ideology of Country Houses, London, 1990, 63-88.

${ }^{45}$ The cold in northern Europe became particularly acute beginning around 1560, when the region experienced the onset of what has been called a 'Little Ice Age'. Brian M. Fagan, The Little Ice Age: How Climate Made History, 1300-1850, New York, 2000. Fagan's work builds on Emmanuel Le Roy Ladurie, Times of Feast, Times of Famine: A History of Climate Since the Year 1000. Garden City, NY, 1971. The implications of these 
climatic conditions for architecture design of the period have been explored in Dean Hawkes, Architecture and Climate: An Environmental History of British Architecture, 1600-2000, London, 2012.

${ }^{46}$ On the importance of light, air, and transparency in Netherlandish urban design, see Christopher Heuer, The

City Rehearsed: Object, Architecture and Print in the Worlds of Hans Vredeman de Vries, London, 2009, 71-2.

${ }^{47}$ See note 28. On the turpentine-oil-soaked window cloths used in Italian buildings, see Attilio Schiaparelli, $L a$ casa fiorentina e i suoi arredi nei secoli XIV e XV, 2 vols, Florence, 1908, 1, 119-24 (125-29 discusses the limited use of window glass). Useful discussions on Italian window furnishings also appear in Ajmar-Wollheim and Dennis, eds, At Home in Renaissance Italy, 34-65.

${ }^{48}$ Simon Stevin, 'De Huysbou': A Reconstruction of an Unfinished Treatise on Architecture, Town Planning and Civil Engineering by Simon Stevin, trans. Charles van den Heuvel, Amsterdam, 2005, 312-3.

49 "En noch somen oock soude willen vele opene Galderijen boven een, ende gantsche doorluchtige Gebouwen maken, als wel eertijds by den Griecken is gedaen, en oock noch in Italien, vermits hen soete lucht en warmte gebruyckelijck: ghewisselijck wy souden ons bedrogen vinden, want onse koude sware Winden, Regen en Sneeuw, verbieden ons sulcx, en soude die ongebruyckelijck maken, en te eerder tot verval brenghen, en souden also met schade onse dolinge te spade bemercken...." Salomon de Bray, Architectura moderna, ofte Bouwinge van onsen tyt, Amsterdam, 1631, 11. My thanks to Almut Trinius and Jasper van Putten for their help in translating this passage.

${ }^{50}$ Wotton, The Elements of Architecture, 55 (emphasis mine).

${ }^{51}$ De Bray, Architectura moderna, 11.

${ }^{52}$ Wotton noted in the building arts "a singular regard, to the nature of the region: every nation, being tyed above al rules whatsoever, to a discretion, of providing against their owne inconveniences: and therefore a good parler in Ægypt would perchance make a good celler in England." Wotton, The Elements of Architecture, 9-10. ${ }^{53}$ The loci classici are scattered throughout Vitruvius's On Architecture, for example in 1.4, where he discusses the salubrity of sites; in I.6, where he describes the division of the city to avoid noxious winds; in I.7, where he discusses the geographic placement of public buildings, depending on their seaside or inland location; and in I.2.7, 1.4.2, VI.3, and VI.4, where he discusses the orientation of rooms according to their function, seasonal use, and need for daylight. See Vitruvius Pollio, On Architecture, trans. Frank Stephen Granger, 2 vols, Cambridge, MA, 1962. With regard to the Italian theorists, some exception can be made for Scamozzi and Serlio, who had spent significant time in northern Europe and more thoroughly addressed foreign building practices in their treatises. 
${ }^{54}$ The relevant passage on shallow roof proportions (Palladio specifies a ratio of 2:9) comes from Andrea Palladio, I quattro libri dell'architettura di Andrea Palladio, 4 vols, Venice, 1, 67. Wotton contests Palladio's principle, arguing that and beauty and the practical dictates of geography are often at odds; see Wotton, The Elements of Architecture, 80. For more on climate and early modern roof construction practices, see the section 'Bauen unter Berücksichtigung von Klimafaktoren' in Jürgen Renn, Wilhelm Osthues, Hermann Schlimme, eds, Wissensgeschichte der Architektur, 3 vols, Berlin, 2014, 3, 173-85.

${ }^{55}$ Paula Henderson, 'Escape from Formality in the Sixteenth-Century English Country House' in Architecture et vie sociale: l'organisation intérieure des grandes demeures à la fin du Moyen Age et à la Renaissance, ed. Jean Guillaume, Paris, 1994, 273, n. 17. See also Henderson, 'The Loggia in Tudor and Early Stuart England: The Adaptation and Function of Classical Form', in Albion's Classicism: The Visual Arts in Britain, 1550-1660, ed. Lucy Gent, New Haven, 1995, 109-45.

${ }^{56}$ For a recent study of the Renaissance sources of this structure, see Michael Kiene, 'Die Kölner Rathauslaube und die Rezeption der italienischen Renaissancearchitektur am Niederrhein', Annali di architettura, 12, 2000, $143-58$.

${ }^{57}$ My thanks to one of the anonymous reviewers for this latter suggestion.

${ }^{58}$ Excerpted and translated by Charles van den Heuvel from Hendrick Stevin's Materiae Politicae, Byvough der Stedenoirdening (1649) in Simon Stevin, 'De Huysbou', 269.

59 'Oriel' derives from the post-classical Latin word oriolum, which may have roots in the post-classical Latin word auleolum, meaning side chapel. Oxford English Dictionary, 3rd ed., 2004, s.v. 'oriel'. The German and Dutch word Erker - derived from the French archière, a defensive structure for launching arrows - initially signified a perch jutting from atop a medieval fortress wall, before also coming to designate similar fenestrated structures in civil architecture. Etymologisch Woordenboek van het Nederlands, 2009, s.v. 'erker'; Etymologisches Wörterbuch der deutschen Sprache, 1975, s.v. 'Erker'. An example of a similar military usage in the English context is the “'ovrystorye' called an 'oryell"” projecting from an embattled stone tower built in 1447 by Richard, duke of York. See C. E. Johnston, 'Sir William Oldhall', The English Historical Review, 25, $1910,716$.

${ }^{60}$ The sense of 'oriel' as porch or antechamber is described in L. F. Salzman, Building in England Down to 1540: A Documentary History, Oxford, 1952, 94-95; and Thomas Hudson Turner, Some Account of Domestic Architecture in England: From Edward I. to Richard II., Oxford, 1883, 82-86. An example of the word's use to indicate a staircase balcony can be found in William Abel Pantin, 'Some Medieval English Town Houses: A 
Study in Adaptation', in Idris Llewelyn Foster and Leslie Alcock, eds, Culture and Environment: Essays in Honour of Sir Cyril Fox, London, 1963, 445-78. In the Cornish dialect, the meaning of 'orrel' as a raised exterior porch survived well into the modern era; see Frederick W. P. Jago, The Ancient Language, and the Dialect of Cornwall, with an Enlarged Glossary of Cornish Provincial Words, Truro, 1882, 228.

${ }^{61}$ Scamozzi noted the correspondence between northern European oriels and Italian balconies: "Nella Germania usano quasi communemente certi luoghi, e bei vederi, che essi chiamano Luoch, e più propriamente Erker, i quali escono alquanto in fuori delle facciate; come i pergomi [sic] nelle chiese.” Vincenzo Scammozzi, L'idea della architettura universale, 2 vols, Venice, 1615, 1, 320.

${ }^{62}$ Thick pillars frequently supported the masonry oriel windows of prestigious late-gothic buildings (famous examples include the Chörlein at the Sebald Vicarage in Nuremberg and the oriel of the Karolinum in Prague), but such construction methods seem largely to disappear over the course of the early modern period.

${ }^{63}$ The use of such iron structures as alternatives to wooden ones is described in Henrick Stevin, Materiae Politicae, excerpted in Simon Stevin, 'De Huysbou', 267.

${ }^{64}$ A particularly stunning case of such architectural addition are the iron oriel windows appended in the later seventeenth century to Robert Sparrowe's House in Ipswich.

${ }^{65}$ Henrick Stevin, Materiae Politicae, excerpted in Simon Stevin, 'De Huysbou', 267

66 "On avance en quelques endroits, principalement en Allemagne, le chassis de verre des fenestrages sur le dehors de neuf ou dix pouces, ce qui apporte beaucoup de commoditez : car par ce moyen, outre ce que l'appuy estant enfermé au dedans de la chambre, ne peut moüiller la chambre par le rejaillissement de la pluye le long du verre, il sert comme de petite table au dedans de ladite chambre. Davantage, on peut sans estre vue, ny ouvrir la fenestre, veoir au dehors non seulement par le devant, mais aussi par les costez et par le bas." Louis Savot, L'architecture françoise des bastimens particuliers, Paris, 1624, 130.

${ }^{67}$ Wolfram Prinz, Die Entstehung der Galerie in Frankreich und Italien, Berlin, 1970; Rosalys Coope, 'The “long gallery": its origins, development, use and decoration', Architectural History, 29, 1986, 43-72, 74-84; Jean Guillaume, 'La galerie dans le château français: place et fonction', Revue de l'Art, 102, 1993, 32-42; Constans and Da Vinha, eds, Les grandes galeries européennes.

${ }^{68}$ Mignot, 'La galerie dans les traités', 39.

${ }^{69}$ See note 42 .

${ }^{70}$ Sebastiano Serlio, Sebastiano Serlio on Architecture, trans Vaughan Hart and Peter Hicks, 2 vols, New Haven, 1996, 2, 23. 
${ }^{71}$ On the seventeenth-century diffusion of Palladianism, see Guido Beltramini, ed. Palladio and Northern Europe: Books, Travellers, Architects, Geneva, 1999.

${ }^{72}$ Lucien Febvre, 'History and psychology', in A New Kind of History: From the Writings of Febvre, ed. Peter Burke, London, 1973, 8.

${ }^{73}$ While population growth in the major cities of Europe prior to the sixteenth century was fairly comparable (with the largest cities concentrated in what was formerly 'Roman' Europe), after 1550 the most dramatic spurts of urban growth occurred in northern territories (Netherlands, France, and Scandinavia); see Jan De Vries, European Urbanization, 1500-1800, Cambridge, MA, 1984. By the late sixteenth century, over half the population living in provinces such as Holland were in cities. Norman John Greville Pounds, An Historical Geography of Europe, Cambridge, 1990, 264.

${ }^{74}$ Vredeman explained that even though the classical and modern Italian authorities had discussed various architectural elements "à la manière antique, italienne, \& la pratique de leur architecture \& bastissage, selon qu'on le trouve en leurs livres \& patrons des aultres maistres, à la mode, coustume \& façon de ce pais là, sans fenestres croisées, \& singulièrement sans requérir beaucoup de lumière, ne haulte profondeur, mais larges, et bien peu haultes. Mais en ce Pais Bas, on a une aultre condition, singulièrement aux villes des grandes négociations, où les places sont petites $\&$ bien chères, là où il fault practiser $\&$ chercher les places en hault, à la plus grande commodité, pour en avoir la clarté...." Hans Vredeman de Vries, Architectura, ou Bastiment, prins de Vitruve, \& des anchiens escrivains, Antwerp, 1577, unpaged.

${ }^{75}$ On the early modern development of the Dutch townhouse typology, see R. Meischke and H. J. Zantkuijl, Het Nederlandse woonhuis van 1300-1800, Haarlem, 1969, 95-125. On the sites and plot sizes of these buildings, see Gerald L. Burke, The Making of Dutch Towns; A Study in Urban Development from the Tenth to the Seventeenth Centuries, London, 1956, esp. 117-53.

${ }^{76}$ Francesco Gregory D'Ierni also remarks on the narrow, tall configuration of Parisian buildings compared to those in Italy. D’Ierni, 'Description de Paris', 166.

${ }^{77}$ On the use of the fenestrated front room or entrance hall in Dutch townhouses by tradesmen and artisans, see Paul Zumthor, Daily Life in Rembrandt's Holland, trans. Simon Watson Taylor, New York, 1963, 40; their furnishings and use for reception in wealthy households is described in Mariët Westermann, “"Costly and curious, full of pleasure and home contentment”: making home in the Dutch Republic', Art \& Home: Dutch Interiors in the Age of Rembrandt, ed. Mariët Westermann, Denver, 2001, 29-31. An example of a stunningly 
fenestrated utilitarian structure is the great armory in Danzig. See Arnold Bartetzky, Das Grosse Zeughaus in Danzig: Baugeschichte, architekturgeschichtliche Stellung, repräsentative Funktion, Stuttgart, 2000.

${ }^{78}$ See the subchapter 'Cleanliness and godliness', in Simon Schama, The Embarrassment of Riches: An Interpretation of Dutch Culture in the Golden Age, New York, 1987, 375-97.

${ }^{79}$ In the context of England, Christy Anderson suggests that the affinity of painters for visual multiplicity related to their sense of the window as a fractured surface made up of many glass pieces, rather than an open frame into a linear, perspectival view. Christy Anderson, "The Secrets of Vision in Renaissance England', The Treatise on Perspective: Published and Unpublished, ed. Lyle Massey, Washington, DC, 2002, 329.

${ }^{80}$ The manuscript was most likely written sometime between 1594 and 1605. See Charles van den Heuvel's codicological analysis in Simon Stevin, 'De Huysbou', 145-51. On the broader relationship of apartment design and nature in Stevin's thought, see Heidi de Mare, 'Het huis, de natuur en het vroegmoderne architectonisch kennisssysteem van Simon Stevin', in Jan de Jong, ed. Wooncultuur in de Nederlanden, 1500-1800 / The Art of Home in the Netherlands, 1500-1800, Zwolle, 2001, 35-59.

${ }^{81}$ Simon Stevin, 'De Huysbou', 309.

${ }^{82}$ Simon Stevin, 'De Huysbou', 307.

${ }^{83}$ A similar compositional scheme, and its relation to rules of composition in early modern painting treatises, has been noted in the case of Vermeer's Woman and Soldier (1658). Paul Taylor, Vermeer, Lairesse and Composition, Zwolle, 2010.

${ }^{84}$ I am grateful to one of the anonymous reviews for this latter suggestion.

${ }^{85}$ On the idealization of these spaces, see C. Willemijn Fock, 'Werkelijkheid of schijn: het beeld van het Hollandse interieur in de zeventiende-eeuwse genreschilderkunst', Oud Holland, 112: 4, 187-246; Heidi de Mare, 'The Domestic Boundary as Ritual Area in Seventeenth-Century' in Heidi de Mare and Anna Vos, eds, Urban Rituals in Italy and the Netherlands: Historical Contrasts in the Use of Public Space and the Urban Environment, Assen, 1993, 108-31.

${ }^{86}$ See especially chapter 3, 'Nicholaes Maes: space as domestic territory' in Martha Hollander, An Entrance for the Eyes: Space and Meaning in Seventeenth-Century Dutch Art, Berkeley, 2002, 103-48.

${ }^{87}$ Scholars have discussed parallels between developments in glazed fenestration and scientific progress (however contested the latter term). Hentie Louw, “"The advantage of a clearer light": the sash-window as a harbinger of an age of progress and enlightenment' in Companion to Contemporary Architectural Thought, eds 
Ben Farmer and Hentie Louw, London, 1993, 300-8; R. E. Danforth, 'Window Glass as a Factor in Human Evolution', The Scientific Monthly, 8: 6, June 1919, 537-41.

${ }^{88}$ Art historians have tied developments in the optical sciences, especially by Jesuit naturalists, to trends in lateRenaissance and baroque interior illumination. Ann Marie Borys, 'Lume di lume: A Theory of Light and its Effects', Journal of Architectural Education, 57: 4, May 2004, 3-9; Frank Fehrenbach, 'Bernini's Light', Art History, 28: 1, February 2005, 1-42.

${ }^{89}$ On this body of commentary, now held at the Zeeuwse Bibliotheek in Middelburg, see Klaas van Berkel, Isaac Beeckman (1588-1637) en de mechanisering van het wereldbeeld, Amsterdam, 1983; Isaac Beeckman, Journal tenu par Isaac Beeckman de 1604 à 1634, ed. Cornelis de Waard, The Hague, 1953.

${ }^{90}$ Fokko Jan Dijksterhuis, 'Labour on lenses: Isaac Beeckman's notes on lens making', in The Origins of the Telescope, eds Albert Van Helden, Sven Dupré and Rob van Gent, Amsterdam, 2010, 257-9, 266.

${ }^{91}$ On the handling of light in this image, see Gregor J. M. Weber, 'Die Empirie des Lichts. Anmerkungen zur Lichtbehandlung bei Johannes Vermeer', Kritische Berichte, 30: 4, 2002, 38.

${ }^{92}$ For aspects of the debate on the use of the camera obscura, see the collection of articles in Sven Dupré, ed. Optics, Instruments and Painting, 1420-1720: Reflections on the Hockney-Falco Thesis. Special edition of Early Science and Medicine, 10: 2, 2005.

${ }^{93}$ Hentie Louw has done the most work to uncover the sash window's history. Hentie Louw and Robert Crayford, 'A Constructional History of the Sash-Window c. 1670-c.1725', part 1 in Architectural History, 41, 1998, 82-130; part 2 in Architectural History, 42, 1999, 173-239. Also see Hentie Louw, 'A window on the past: what the study of historic fenestration practices can tell us about the nature of architecture', Practice and Science in Early Modern Italian Building: Towards an Epistemic History of Architecture, ed. Hermann Schlimme, Milan, 2006, 43-50.

94 Thornton, Seventeenth-Century Interior Decoration, 81.

${ }^{95}$ Hawkes, Architecture and Climate.

${ }^{96}$ Wotton, The Elements of Architecture, 56.

${ }^{97}$ Quoted in Walter Bernan, On the History and Art of Warming and Ventilating Rooms and Buildings, 2 vols, London, 1845, 1, 124.

${ }^{98}$ Simon Stevin, 'De Huysbou', 270.

${ }^{99}$ Raphael Holinshed, Chronicles of England, Scotland and Ireland, 6 vols, London, 1587, 1, 109.

${ }^{100}$ Wotton, The Elements of Architecture, 56. 
${ }^{101}$ John Evelyn, 5 October 5 1641, in The Diary of John Evelyn, ed. William Bray, 2 vols, London, 1901, 1, 278.

${ }^{102}$ Such features are enumerated, for instance, in the inventories of Bess of Hardwick, whose bedroom in Hardwick Hall contained "too Curtins of red Cloth for the windowes, three Coverletes to hang before a windowe, a Coverlett to hang before a Dore,” along with many blankets, curtains, quilts. See Santina M. Levey, ed. Of Houshold Stuff: The 1601 Inventories of Bess of Hardwick, London, 2001, 53.

${ }^{103}$ Deborah Howard, 'Seasonal apartments in Renaissance Italy', Artibus et Historiae, 22: 43, 2001, 134.

${ }^{104}$ Holinshed writes: "I will not speake of iron, glasse, and such like, which spoile much wood, and yet are brought from other countries better cheepe than we can make them here at home...." Holinshed, Chronicles, 1, 156.

105 The actual extent of a fuel crisis, as opposed to contemporary fears of such, has been a matter of scholarly debate. For a few texts from the vast literature, see Paul Warde, 'Fear of wood shortage and the reality of the woodland in Europe, c.1450-1850', History Workshop Journal, 62: 1, Autumn 2006, 28-57; for the situation in the Baltic states, Per Eliasson and Sven G. Nilsson, "YYou should hate young oaks and young noblemen": the environmental history of oaks in eighteenth- and nineteenth-century Sweden', Environmental History, 7: 4, October 2002, 671-3; for a classic study on forests, timber and the English navy, see Robert Greenhalgh Albion, Forests and Sea Power: The Timber Problem of the Royal Navy, 1652-1862, Cambridge, MA, 1926.

${ }^{106}$ By 1615, in order to slow the destruction of timber otherwise serviceable for building the navy, James I declared that all glass in England must use recently invented coal-burning furnaces. The French did not adopt the technology till about 1700, when its use trickled into the country; the technology did not become widespread in France till 1800. Royal ordinances in France attempted to stem glass production in the late eighteenth century, but the fuel crisis seems to have continued unabated into the eighteenth century. Godfrey, 38-74; Scoville, 41-2.

${ }^{107}$ John Norden, The Surveyors Dialogue Divided into Five Books, London, 1607, 214.

${ }^{108}$ Wolfgang Schivelbusch, Disenchanted Night: The Industrialization of Light in the Nineteenth Century, trans. Angela Davies, Berkeley, 1988; Jonathan Crary, 24/7: Late Capitalism and the Ends of Sleep, New York, 2013. 